\title{
Unusual changes of zooplankton fatty acid composition in the northern Adriatic during the 1991 mucilage event
}

\author{
Mirjana Najdek* \\ Ruđer Bošković Institute, Center for Marine Research, 52210 Rovinj, Croatia
}

\begin{abstract}
Fatty acids and pristane/heptadecane $\left(\mathrm{Pr} / \mathrm{C}_{17}\right)$ ratio were analysed in zooplankton samples collected with a sediment trap in the northeastern Adriatic Sea from April 1991 to June 1992 in 2 to 6 wk intervals. Saturated (SAT; 22 to $68 \%$ of total fatty acid mass fraction), monounsaturated (MONO; 20 to $39 \%$ ), and polyunsaturated (PUFA; 6 to $49 \%$ ) fatty acid proportions, total fatty acid mass fraction ( 2.3 to $46.5 \mathrm{mg} \mathrm{g}^{-1}$ dry $w t$ ), and $\mathrm{Pr} / \mathrm{C}_{17}$ ratio $(0.5$ to 27 ) varied significantly during the investigated period. Unusually low fatty acid mass fractions (2.3 to $5.1 \mathrm{mg} \mathrm{g}^{-1}$ dry wt), PUFA proportions (6\%), and $\mathrm{Pr} / \mathrm{C}_{17}$ ratio (<1) measured in summer 1991 were ascribed to a drastic zooplankton starvation due to a mucilage event, a phenomenon that can occur periodically (every 10 to $50 \mathrm{yr}$ ) in the region. Low PUFA proportions (12\%) were also measured in winter/early spring 1992, but the C14:0 and C16:1 proportions, and $\mathrm{Pr} / \mathrm{C}_{17}$ ratio (9 to 27 ) exhibited their highest values of the investigated period. This indicated more favourable feeding conditions and significant phytoplankton contributions in the zooplankton diets than in summer 1991. The highest total mass fraction (12.2 to $46.5 \mathrm{mg} \mathrm{g}^{-1} \mathrm{dry}$ wt) and PUFA proportions ( 30 to $49 \%$ ) were observed during spring and autumn, when the food supply was probably sufficient and diverse. The oleic acid (C18:1n9) proportions (12 to $22 \%$ ) in the northeastern Adriatic were higher than in other marine regions
\end{abstract}

KEY WORDS: Fatty acids · Zooplankton $\cdot$ Northeastern Adriatic $\cdot$ Mucilage event

\section{INTRODUCTION}

Fatty acid composition of the mesozooplankton natural community depends on sea depth and temperature, geographical location, and season, particularly in relation to food availability, and can vary greatly during zooplankton starvation (Lee et al. 1971, Morris 1971, Lee 1974, Kattner et al. 1981, Kattner 1989, Serrazanetti et al. 1994b, Ederington et al. 1995). Zooplankton starvation can occur during unusual events in the marine environment, like the massive appearance of mucilaginous aggregates in the northern Adriatic (Malej 1995).

\footnotetext{
•E-mail:najdek@more.cim.irb.hr
}

Remarkable mucilaginous events in the summers of 1988,1989 and 1991 can be related to periodical unusual oceanographic conditions (Crisciani et al. 1991, Degobbis et al. 1995). In such conditions copepod stocks might be too low to control phytoplankton growth during the exponential phase, and subsequent grazing pressure is inefficient due to deterrent exudations produced in the stationary phase (Herndl 1992, Malej \& Harris 1993).

The purpose of this study was to describe changes in zooplankton fatty acid composition leading up to and during a mucilage event in comparison with other periods of the year. Particularly, the hypothesis that the presence of mucilaginous material might significantly reduce the availability of food to zooplankton was tested to yield additional information about possible consequences of the mucilage phenomenon on the northern Adriatic ecosystem. 


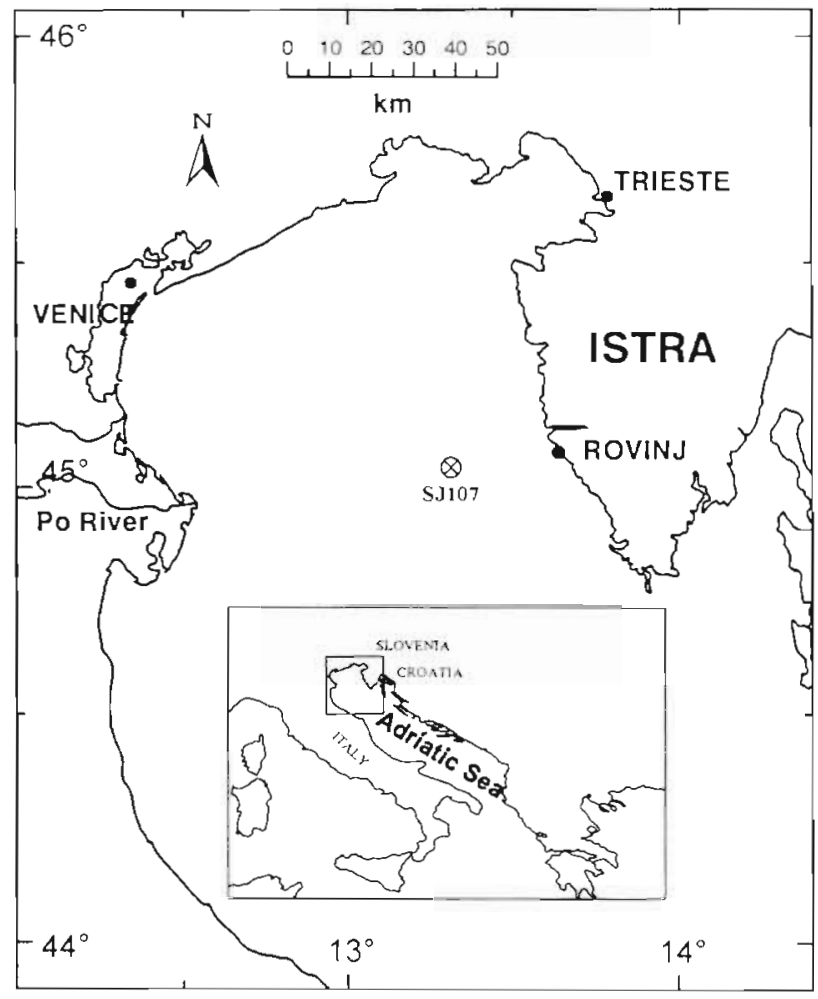

Fig. 1. Sampling location in the northern Adriatic Sea

\section{MATERIAL AND METHODS}

Sampling. A sediment trap was moored at $23 \mathrm{~m}$ depth on a permanent CMR oceanographic station (SJ107, depth $37 \mathrm{~m}$ ) in the open waters of the northeastern Adriatic, $25 \mathrm{~km}$ off Rovinj $\left(45^{\circ} 2.8^{\prime} \mathrm{N}, 13^{\circ}\right.$ 19.0' E; Fig. 1). Cups were prefilled with brine solution containing $5 \%$ formalin to preserve the deposited material (Puškarić et al. 1992). Samples were collected in 2 to 6 wk intervals from 25 April 1991 to 15 June 1992. Zooplankton accounted for 20 to $89 \%$ of the total wet weight of the collected material. Zooplankton organisms were isolated from wet samples using small forceps with sharpened ends under the dissecting microscope at 30 to $50 \times$ magnification. Between 100 and 300 individuals were taken for an analysis, except in July 1991 when only 55 individuals could be isolated (see Table 1).

The sticky mucilage obstructs plankton net mesh and makes separation of individual animals difficult, so traditional sampling mechanisms were impractical. The sediment trap was considered as a suitable alternative technique for zooplankton sampling and has previously been successfully used for zooplankton study (Fargrave et al. 1989). The quantities of mucilage and zooplankton entangled in mucous material were absent or very low in the samples collected by the trap. All zooplankton collected had intact antennae and tissues, without visible signs of decomposition. This suggested that the zooplankton entered the trap alive and were killed by the formalin.

Of all the preservatives (Knauer et al. 1984, Lee et al. 1992) and poisons (Körtzinger et al. 1994) usually used in seciment traps, formalin is the most effective at suppressing the biological activity of bacteria and grazers, thus allowing collection of representative zooplankton samples. This compound solidifies the proteinaceous matrix of the exoskeleton, thereby preventing leaching of intracellular fluids (Lee et al. 1992).

To test if different sampling methods can affect the zooplankton fatty acid profiles, 2 samples were collected in June 1992 by horizontal hauling of a plankton net ( $1 \mathrm{~m}$ mouth diameter, $250 \mu \mathrm{m}$ Nitex mesh) in the upper water column for 2 min (see Table 1).

Extraction and analysis. Fatty acid extraction and isolation procedures were described in detail previously (Najdek et al, 1994). GLC analyses were carried out in a Hewlett Packard 5730A gas chromatograph with a glass capillary column, coated with methylsilicone $(12 \mathrm{~m} \times 0.2 \mathrm{~mm})$, programmed to increase the temperature from 70 to $270^{\circ} \mathrm{C}$ at the rate of $4^{\circ} \mathrm{C} \mathrm{min}^{-1}$. Injector and detector temperatures were 250 and $300^{\circ} \mathrm{C}$, respectively. Nitrogen was used as carrier and make-up gas. Peaks were identified by means of reference standards and by comparison of relative retention indices. The compounds were quantified by internal standards, octadecene C18:1 for hydrocarbons and heptadecanoic acid C17:0 for fatty acids. Blank readings were made daily, all glassware was kept in hot sulfochromic acid and rinsed thoroughly with distilled water and dichloromethane (DCM) before use.

Data analysis. Statistical data analysis was done on a $P C$ using commercial software packages (Systat 5.0). One-way analysis of variance (ANOVA) was used to verify statistical significance $(p<0.05)$ of the differences in the fatty acid profiles between sampling periods and between sampling methods (sediment trap and zooplankton net). Pairwise comparison probabilities were obtained by the Tukey post hoc test.

\section{RESULTS}

\section{Zooplankton species in samples}

In all sediment trap samples, numbers of copepods and cladocerans were much higher than those of other species (chaetognats, hydromedusae, doliolids, nauplii, zoea, and fish larvae and eggs), but in variable proportions (Table 1). Copepods accounted for more than $80 \%$ of the total count in most of the samples. Their relative abundance was slightly lower in summer 


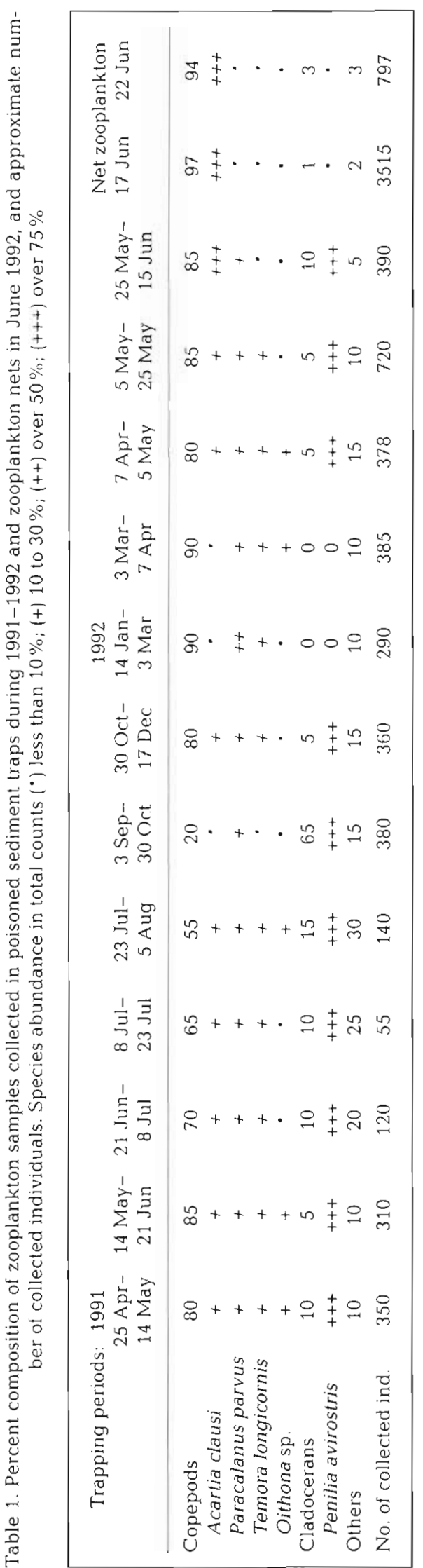

1991 (55 to $70 \%$ ), when the number of collected individuals (55 to 140 ) was several times less than those of other sampling periods (290 to 720 ). Only in 1 sample did copepods not dominate $(20 \%)$ over cladocerans $(65 \%)$. In all other samples cladocerans varied from zero up to $15 \%$ During summer 1991 the contribution of other species ( 20 to $30 \%$ ) was higher than in the remainder of the sampling periods ( 5 to $15 \%$ ) (Table 1 ).

Of the copepod species, the best represented were Paracalanus parvus, Acartia clausi, Temora longicornis and Oithona sp.; Penilia avirostris highly dominated the cladocerans.

In the net samples collected in June 1992, copepods (mainly Acartia clausi, $>75 \%$ ) contributed more than $90 \%$ of the total counts, cladocerans $1 \%$, and other species 2 and $3 \%$ (Table 1).

\section{Principal fatty acids and their temporal changes}

Of saturated fatty acids (SAT; 22 to $68 \%$ of the total fatty acid mass fraction) the main component was palmitic acid C16:0 (15 to $47 \%$ ), followed by myristic C14:0 (4 to $15 \%$ ) and stearic acid C18:0 (1 to $9 \%$ ). The total contribution and temporal changes of other identified saturated acids (C15:0, C17:0, C19:0, C20:0, C22:0) were insignificant $(<3 \%)$.

Oleic acid (C18:1n9, 12 to $22 \%$ ) dominated the monounsaturated fraction (MONO; 20 to $39 \%$ ), occurring in higher proportions than palmitoleic acid (C16:1n $7 ; 5.2$ to $16.6 \%$ ) by a factor of between 1.1 and 4.0. Polyunsaturated fatty acids (PUFA) varied within the largest range of values (5.5 to $49.1 \%$ ). The best represented PUFAs were docosahexaenoic (C22:6n3; 2 to $30 \%)$ and eicosapentaenoic (C20:5n3; 1 to $15 \%)$ acids. Other unsaturated acids (C20:1, C22:1, C18:2n6, C18:3n3, C18:4n3) occurred in low proportions (<3\%), without defined temporal changes.

The total fatty acid mass fraction ranged from 2.3 to $46.5 \mathrm{mg} \mathrm{g}^{-1}$ dry wt. The highest values $(12.2$ to $46.5 \mathrm{mg}$ $\mathrm{g}^{-1}$ dry wt) were measured in spring 1991/1992 and autumn (25 April to 21 June 1991, 3 September to 17 December 1991 and 5 May to 15 June 1992) and the lowest values ( 2.3 to $5.1 \mathrm{mg} \mathrm{g}^{-1} \mathrm{dry} \mathrm{wt}$ ) in summer 1991 (21 June to 5 August 1991), while in winter/early spring (14 January to 5 May 1992) they varied between 8.1 and $11.3 \mathrm{mg} \mathrm{g}^{-1}$ dry wt (Fig. 2).

Significant changes in the relative proportions of the fatty acid components also occurred during the investigated period. While the significant decreases of the principle PUFA proportions in summer 1991 and winter/early spring period 1992 corresponded to total mass fraction decreases, the proportions of SAT (C16:0 or C14:0) and MONO (C16:1n7) compounds increased (Fig. 2). 

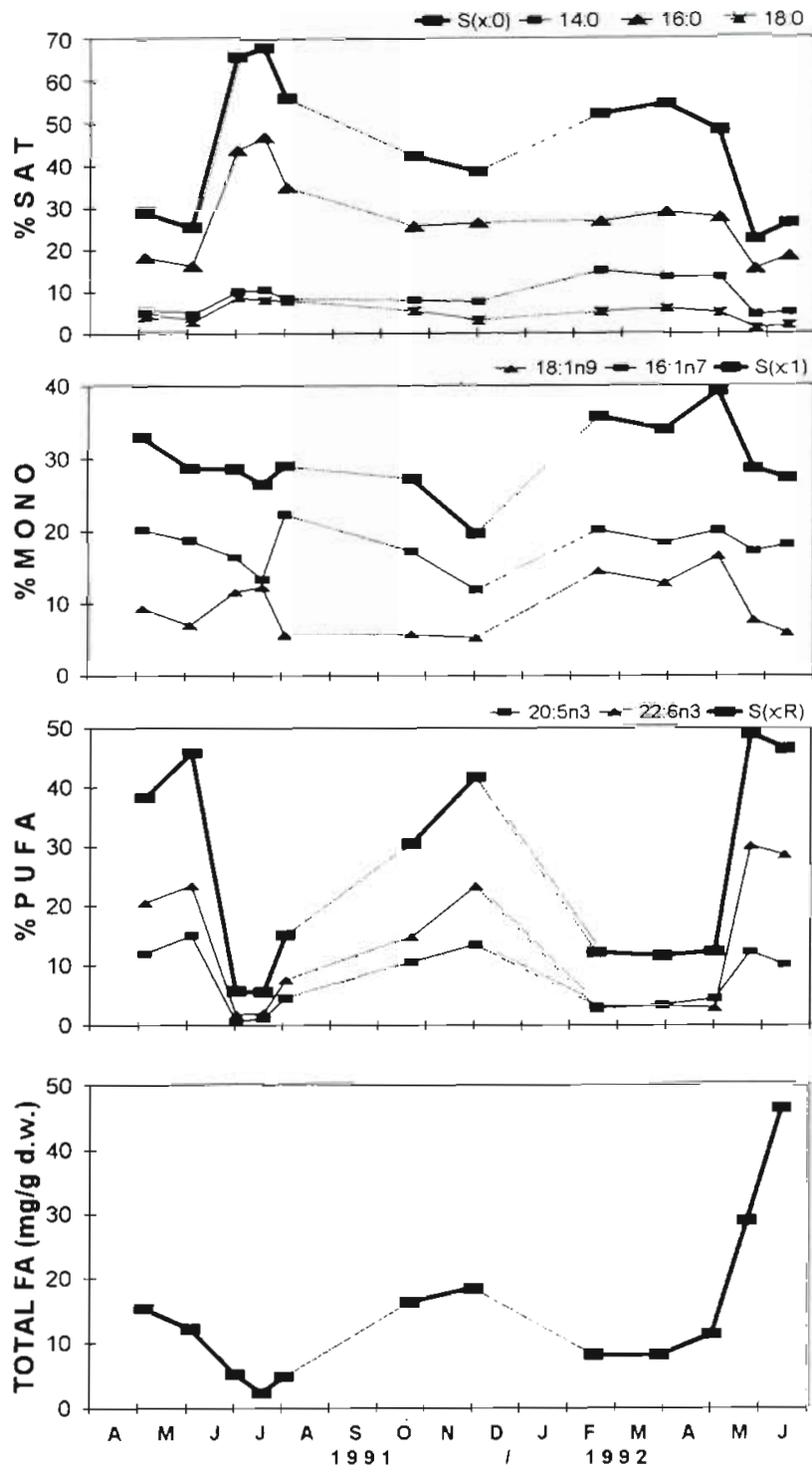

Fig. 2. Proportions of saturated (\%SAT), monounsaturated (\%MONO) and polyunsaturated (\%PUFA) fatty acids, individual and total $\mathrm{s}(\mathrm{x}: 0), \mathrm{s}(\mathrm{x}: 1), \mathrm{s}(\mathrm{x}: \mathrm{R})$, respectively; and total fatty acid mass fraction in zooplankton samples. Data are given on midpoints of each sampling period from April 1991 to June 1992

$\mathrm{Pr} / \mathrm{C}_{17}$ ratio values below unity $(0.5$ to 1$)$ and lower UNS/SAT (unsaturated to saturated) ratio $(0.5$ to 0.8 ) were obtained for summer 1991 compared to higher values in other sampling periods (Table 2). In contrast, $\operatorname{Pr} / C_{17}$ ratio were much higher ( 9 to 27 ) in winter/early spring 1992, and intermediate in the rest of the samples (3 to 7.5). The highest UNS/SAT ratios (up to 3.5) were obtained in spring 1991 and spring 1992.

Three groups of samples with similar characteristics were identified using ANOVA (Table 2). Group 1 included spring and autumn samples, with much higher proportions of PUFAs, and consequently higher UNS/SAT ratio than in Group 2 samples, which were those collected in summer 1991. Intermediate values for PUFA proportions and UNS/SAT ratio were typical for Group 3 samples, those collected in winter and early spring 1992, which, in addition, were characterized by the highest $\mathrm{Pr} / \mathrm{C}_{17}$ ratio.

The Tukey post hoc test of pairwise comparison probabilities confirmed high statistical significance of changes in the relative proportions of the principle zooplankton fatty acid components observed during the investigated period (Table 3). While the C16:0 contributions were significantly different among all 3 sample groups, for C14:0 this was obtained only for the high Group 3 values (Fig. 2). The same was confirmed for the monounsaturated C16:1n 7 . The proportions of the principle PUFAs (C20:5n3 and C22:6n3) and UNS/SAT ratios in Group 2 and 3 were essentially the same, but they were significantly lower than in Group 1. For the other, minor fatty acid components, changes were not statistically significant. In contrast, the $\mathrm{Pr} / \mathrm{C}_{17}$ ratio values were clearly different among the 3 sample groups.

\section{Comparisons between sampling techniques}

Possible differences in fatty acid composition arising from different sampling methods were also tested with ANOVA. Zooplankton was sampled twice with a plankton net in June 1992 and analysed immediately after collection without addition of any preservative. The obtained results (Table 2) were compared with sediment trap data for the preceding period (MayJune 1992), and combined with other similar samples (i.e. with Group 1 samples; Table 2).

The principal fatty acid components (SAT C14:0, C16:0, C18:0; MONO C18:1n9, C16:1n7; and PUFA $\mathrm{C} 18: 4 \mathrm{n} 3, \mathrm{C} 18: 3 \mathrm{n} 3, \mathrm{C} 18: 2 \mathrm{n} 6, \mathrm{C} 20: 5 \mathrm{n} 3$ and $\mathrm{C} 22: 6 \mathrm{n} 3)$ were compared. The proportions of all these components measured at Stn SJ107 did not differ, regardless of the zooplankton sampling method (Table 4).

\section{Comparisons between marine regions}

Assuming that the use of different sampling methods does not affect fatty acid analysis results, sediment trap data obtained in this study was compared with net zooplankton data from other marine regions by means of ANOVA (Table 4). For this comparison, data for all sampling periods were used, except those collected in summer 1991, when the mucilage event occurred. Comparison was made with the Gulf of 
Table 2. Fatty acid composition (\%) and $\mathrm{PR} / \mathrm{C}_{17}$ (pristane/heptadecane) and UNS/SAT (unsaturated/saturated) ratios in $3 \mathrm{groups}$ (identified using ANOVA; Group 1: 25 April to 21 June 1991, 3 September to 17 December 1991, 5 May to 15 June 1992; Group 2: 21 June to 5 August 1991; and Group 3:14 January to 5 May 1992) of zooplankton samples with similar characteristics collected in sediment traps, and in samples collected by zooplankton net in June 1992. M: mean; SD: standard deviation; n: number of samples

\begin{tabular}{|c|c|c|c|c|c|c|c|c|c|c|c|c|}
\hline \multirow{3}{*}{ Fatty acid } & \multicolumn{9}{|c|}{ - Sediment trap } & \multirow{2}{*}{\multicolumn{3}{|c|}{ Net $(n=2)$}} \\
\hline & \multicolumn{3}{|c|}{ Group $1(\mathrm{n}=6)$} & \multicolumn{3}{|c|}{ Group $2(n=3)$} & \multicolumn{3}{|c|}{ Group $3(n=3)$} & & & \\
\hline & Range & $M$ & SD & Range & $\mathrm{M}$ & $\mathrm{SD}$ & Range & M & $\mathrm{SD}$ & Range & $\mathrm{M}$ & $\mathrm{SD}$ \\
\hline C14:0 & $4.4-7.9$ & 5.7 & 1.4 & $8.3-10.4$ & 9.6 & 0.9 & $13.3-14.9$ & 13.8 & 0.7 & $6.3-9.2$ & 7.8 & 1.5 \\
\hline C15:0 & $0.5-1.7$ & 0.9 & 0.4 & $1.3-1.8$ & 1.5 & 0.2 & $1.2-4.2$ & 2.9 & 1.2 & $0.6-0.8$ & 0.7 & 0.1 \\
\hline $\mathrm{C} 16: 0$ & $15.3-26.3$ & 19.9 & 4.3 & $34.8-46.7$ & 41.8 & 5.1 & $26.6-28.8$ & 27.7 & 0.9 & $15.9-20.5$ & 18.2 & 2.3 \\
\hline $\mathrm{C} 17: 0$ & $0.2-0.4$ & 0.3 & 0.0 & $0.6-1.1$ & 0.8 & 0.2 & $0.2-1.1$ & 0.6 & 0.4 & $0.2-0.6$ & 0.4 & 0.2 \\
\hline C18:0 & $1.3-5.3$ & 3.0 & 1.3 & $7.8-8.6$ & 8.1 & 0.3 & $4.9-5.8$ & 5.3 & 0.4 & $3.3-4.9$ & 4.1 & 0.8 \\
\hline Other $(\mathrm{x}: 0)$ & $0.0-1.4$ & 0.2 & 0.3 & $0.1-1.6$ & 0.5 & 0.4 & $0.0-1.4$ & 0.4 & 0.5 & $0.1-0.3$ & 0.2 & 0.1 \\
\hline $\mathrm{S}(\mathrm{x}: 0)$ & $22.3-42.2$ & 30.6 & 7.3 & $55.9-67.6$ & 63.2 & 5.2 & $48.3-54.4$ & 51.6 & 2.5 & $29.4-37.4$ & 33.4 & 4.0 \\
\hline $\mathrm{C} 16: 1 \mathrm{n} 7$ & $5.2-9.3$ & 6.8 & 1.4 & $5.6-12.2$ & 9.8 & 2.9 & $12.8-16.6$ & 14.6 & 1.5 & $6.5-8.7$ & 7.6 & 1.1 \\
\hline C18:1n9 & $11.9-20.2$ & 17.2 & 2.6 & $13.3-22.3$ & 17.3 & 3.7 & $18.4-20.2$ & 19.6 & 0.8 & $16.7-19.1$ & 17.9 & 1.2 \\
\hline Other(x:1) & $0.9-2.9$ & 1.7 & 0.6 & $0.2-0.7$ & 0.4 & 0.2 & $0.3-1.4$ & 1.0 & 0.4 & $1.7-2.5$ & 2.1 & 0.4 \\
\hline$S(x: 1)$ & $19.6-32.9$ & 27.4 & 3.9 & $26.5-28.9$ & 27.9 & 1.1 & $33.9-39.2$ & 36.3 & 2.2 & $26.1-30.5$ & 28.3 & 2.2 \\
\hline$C 20: 5 n 3$ & $10.2-14.9$ & 12.3 & 1.6 & $0.6-4.5$ & 2.1 & 1.7 & $3.2-4.5$ & 3.7 & 0.5 & $11.4-13.8$ & 12.6 & 1.2 \\
\hline $\mathrm{C} 222: 6 \mathrm{n} 3$ & $14.8-30.2$ & 23.5 & 5.1 & $1.8-7.6$ & 3.8 & 2.7 & $2.8-3.3$ & 2.9 & 0.2 & $21.5-26.1$ & 23.8 & 2.3 \\
\hline Other(x:R) & $0.5-3.2$ & 2.1 & 0.8 & $0.0-1.9$ & 0.9 & 0.7 & $0.9-2.6$ & 1.8 & 0.5 & $2.1-3.7$ & 2.9 & 0.8 \\
\hline$S(x: R)$ & $30.5-49.1$ & 42.0 & 6.2 & $5.6-15.1$ & 8.7 & 4.5 & $11.6-12.4$ & 12.1 & 0.3 & $34.5-42.1$ & 38.3 & 3.8 \\
\hline $\mathrm{P}_{5} / \mathrm{C}_{17}$ & $2.6-7.5$ & 5.4 & 1.4 & $0.5-1.0$ & 0.7 & 0.2 & $9.4-26.6$ & 15.6 & 7.8 & $5.3-7.5$ & 6.4 & 1.1 \\
\hline UNS/SAT & $1.4-3.5$ & 2.4 & 0.7 & $0.5-0.8$ & 0.6 & 0.1 & $0.8-1.1$ & 0.9 & 0.1 & $1.5-2.7$ & 2.1 & 0.6 \\
\hline
\end{tabular}

Trieste (northeastern corner of the Adriatic; Fig. 1; Serrazanetti et al. 1994a, b), the Baltic Sea (Finnish coastal waters; Kaitaranta et al. 1986), and the southern North Sea and Wadden Sea (Kattner et al. 1981). Copepods constituted 60 to $80 \%$ of the mesozooplankton samples from these regions, with a species composition similar to the samples from Stn SJ107.

Table 3. Pairwise probabilities (p1, p2, p3) for variation in saturated, monounsaturated and polyunsaturated fatty acid proportions, and UNS/SAT and $\mathrm{PR} / \mathrm{C}_{17}$ ratios of the zooplankton collected in sediment traps. Significant differences are given in bold $(p<0.05)$ p1. Group 1 vs Group 2; p2: Group 1 vs Group 3; p3: Group 2 vs Group 3

\begin{tabular}{|lccc|}
\hline Fatty acid & $\mathrm{p} 1$ & $\mathrm{p} 2$ & $\mathrm{p} 3$ \\
\hline $\mathrm{C} 14: 0$ & 0.293 & $\mathbf{0 . 0 0 0}$ & 0.372 \\
C16:0 & $\mathbf{0 . 0 0 0}$ & $\mathbf{0 . 0 0 0}$ & $\mathbf{0 . 0 0 0}$ \\
C18:0 & 0.076 & 0.983 & 0.950 \\
Other $(\mathrm{x}: 0)$ & 0.998 & 0.998 & 0.998 \\
C16:1n7 & 0.546 & $\mathbf{0 . 0 0 0}$ & 0.122 \\
C18:1n9 & 1.000 & 0.842 & 0.949 \\
Other $(\mathrm{x}: 1)$ & 0.945 & 0.999 & 1.000 \\
C20:5n3 & $\mathbf{0 . 0 0 0}$ & $\mathbf{0 . 0 0 0}$ & 1.000 \\
C22:6n3 & $\mathbf{0 . 0 0 0}$ & $\mathbf{0 . 0 0 0}$ & 1.000 \\
Other (x:R) & 0.998 & 1.000 & 1.000 \\
UNS/SAT & $\mathbf{0 . 0 1 0}$ & $\mathbf{0 . 0 4 5}$ & 0.882 \\
Pr/C 17 & $\mathbf{0 . 0 0 3}$ & $\mathbf{0 . 0 0 6}$ & $\mathbf{0 . 0 0 0}$ \\
\hline
\end{tabular}

The differences between the mesozooplankton samples from Stn SJ107 and from the other 3 compared regions were not statistically significant for most of the fatty acid components, except for oleic acid (C18:1n9) proportions (Table 4). The values for this acid were much lower in the Gulf of Trieste and Baltic Sea compared to Stn SJ107.
Table 4. Summary statistics of pairwise probabilities for variation in saturated, monounsaturated and polyunsaturated fatty acid proportions of the zooplankton collected in sediment traps (SJ107 trap) vs proportions in the zooplankton net (SJ107 net) in this study and vs proportions found in other net studies in the Baltic Sea (Kaitaranta et al. 1986), North Sea (Kattner et al. 1981) and Gulf of Trieste (Serrazanetti et al. 1994). Significant differences are given in bold $(p<0.05)$

\begin{tabular}{|c|c|c|c|c|}
\hline \multirow{2}{*}{ Fatty acid } & \multicolumn{4}{|c|}{ SJ107 trap vs: } \\
\hline & $\begin{array}{c}\text { Baltic } \\
\text { Sea }\end{array}$ & $\begin{array}{l}\text { North } \\
\text { Sea }\end{array}$ & $\begin{array}{l}\text { Gulf of } \\
\text { Trieste }\end{array}$ & $\begin{array}{c}\text { SJ } 107 \\
\text { net }\end{array}$ \\
\hline C14:0 & 0.999 & 0.517 & 1.000 & 0.986 \\
\hline C16:0 & 0.142 & 0.894 & 0.267 & 0.993 \\
\hline C18:0 & 1.000 & 0.974 & 1.000 & 0.999 \\
\hline C16: $\ln 7$ & 0.128 & 1.000 & 0.209 & 0.988 \\
\hline C18:1n9 & 0.000 & 0.111 & 0.000 & 0.992 \\
\hline C18:3n3 & 1.000 & 1.000 & 1.000 & 1.000 \\
\hline $\mathrm{C} .20 .5 \mathrm{n} 3$ & 0.076 & 1.000 & 1.000 & 1.000 \\
\hline $\mathrm{C} 22: 6 \mathrm{n} 3$ & 0.996 & 0.985 & 0.838 & 1.000 \\
\hline
\end{tabular}




\section{DISCUSSION}

The hypothesis that zooplankton tend to conserve their PUFA reserves (Lee 1974; PUFAs are needed for production of egg membranes) is supported for planktonic copepods by laboratory starvation experiments in which lipid reserves were rapidly used (Lee et al. 1971) and saturated fatty acids increased without significant change in PUFAs (Ederington et al. 1995). Natural populations in the North Sea showed reduction in diversity of fatty acid composition without reduction in PUFA proportion (Kattner \& Krause 1989). In contrast, in the northeastern Adriatic mesozooplankton significant decreases of PUFA proportions corresponding to increases of saturated fractions occurred in summer 1991 and winter/early spring 1992, when the total lipid reserves were greatly reduced. Consequently, lower UNS/SAT ratios were measured in copepods in these 2 periods compared to the other sampling periods.

Parameters indicating food potential for zooplankton were monitored at Stn SJ107 at the beginning and end of each sediment trap sampling period. Mean total chlorophyll a concentration for the upper $20 \mathrm{~m}$ at Stn SJ107 was generally lower in summer 1991 (0.20 to $0.45 \mu^{-1}$ ) and winter/early spring 1992 $\left(0.40\right.$ to $0.50 \mu \mathrm{g}^{-1}$ ) than during the other sampling periods $\left(0.2\right.$ to $\left.1.1 \mu \mathrm{g} \mathrm{I}^{-1}\right)$. The organic suspended matter values did not differ significantly, varying between 0.5 and $1.2 \mu \mathrm{g} \mathrm{l}^{-1}$ in each of these 3 periods. Microzooplankton abundances and diversity in summer 1991 ( 3 to 50 ind. $1^{-1}$ ) were unusually lower than in other sampling periods 40 to 380 ind. $1^{-1}$; Kršinić 1995). However, these variations of food quantities (living and detritus) were not high enough to be the only reason for the observed changes in the mesozooplankton fatty acid composition, especially because copepods become less selective when their preferred food is lacking (Donaghay \& Small 1979, Kleppel et al. 1988).

Through summer 1991 large quantities of mucilaginous aggregates were present within the water column from mid June. However, polysaccharide exudation by phytoplankton might have started earlier, before the material reached saturation levels and started to aggregate (Degobbis et al. 1995). Inhibition of zooplankton grazing by this material can be inferred, leading to a large decrease of the relative contribution of the principle PUFA components, although the aggregates themselves could serve as a source of high quality PUFAs (Najdek 1996). In fact, the deterrent effects of diatom exudations on copepod feeding have been shown in laboratory experiments with the dominant northern Adriatic species (Malej \& Harris 1993). Moreover, it was shown that a major fraction of free-living zooplankton is unable to use phytoplankton when it is embedded in mucous matrix (Bochdansky \& Herndl 1992). In fact, while larger nauplii or some copepod species (e.g. Temora stylifera) can feed on marine snow and can accumulate in the aggregates, the dominant species at Stn SJ107 during summer (Acaria clausi and Paracalanus parvus) were neither present in aggregates nor eating aggregated diatoms. In addition, the reproductive rates of micro- and mesozooplankton probably were decreased when embedded in aggregates (Bochdansky \& Herndl 1992, Kršinić 1995). All these factors might have also contributed to the observed low abundance of free-living zooplankton in summer 1991.

Another unusual feature of summer 1991 was the very low $\mathrm{Pr} / \mathrm{C}_{17}$ ratio, which also indicated an inaccessibility of food to the copepods. Actually, during the warm season, when zooplankton feeding is more active, a significant buildup of pristane usually occurs. This compound is the primary hydrocarbon component of marine copepods throughout the season (Blumer et al. 1964, Lee 1974, Saliot 1981, Serrazanetti et al. 1994a). It occurs in high concentrations and prevails over heptadecane $\left(C_{17}\right)$ even when animals are starying (Blumer et al. 1964). In apparent contrast with these findings, $\mathrm{Pr}_{1} / \mathrm{C}_{17}$ ratios in copepods at Stn SJ107 were very low (even below unity). The lack of pristane would reduce buoyancy, compromising the capability of getting food, and thereby possibly reducing the average life-span.

Interestingly, in August 1991 the proportion of PUFA in the mesozooplankton from the Gulf of Trieste (35\%; Serrazanetti et al. 1994b) was several times higher than at Stn SJ107 in June and July. In August the aged mucilaginous aggregates transferred to the deeper layers, and it is possible that the action of the exudates on mesozooplankton was reduced. Unfortunately August samples were not taken at Stn SJ107, and it is not possible to confirm this hypothesis.

In contrast with summer 1991, the significant decrease of PUFA proportions in winter/early spring 1992 should not be ascribed to food shortage, because the $\mathrm{Pr} / \mathrm{C}_{17}$ ratio remained high in this period. Moreover, the higher proportions of palmitoleic (C16:1n7) and myristic (C14:0) fatty acids, measured in winter/ early spring 1992 compared with other spring and autumn samples, indicated an increase of phytoplankton in the zooplankton diets. Higher proportions of myristic acid were determined in winter copepods of the Gulf of Trieste in respect to other seasons (Serrazanetti et al. $1994 \mathrm{~b}$ ). In the same samples $\mathrm{Pr}_{\mathrm{C}} \mathrm{C}_{17}$ ratios were as high as at Stn SJ107 (Serrazanetti et al. 1994a). A very similar fatty acid pattern characterized various phytoplankton species (Mayzaud et al. 1989, 
Volkman et al. 1989) as well as the chain-forming diatom Skeletonema costatum, which progressively replaced the dominant small forms of flagellates and some diatoms in late winter 1992 in the northern Adriatic.

The zooplankton collected in spring 1991, spring 1992 and autumn 1991 were characterized by relatively low proportions of saturated fatty acids and significantly higher values for $C 20: 5 n 3$ and $C 22: 6 n 3$ fatty acids compared with other periods. These data suggest that the food supply was sufficient and diverse, as found in other marine regions (Kattner et al. 1981, Kaitaranta et al. 1986, Kattner \& Krause 1989, Serrazanetti et al. 1994b). Remarkably, the oleic acid proportions in Stn SJ107 samples (C18:1n9, 12 to $22 \%$ were significantly higher than in spring and summer copepods from the nearby Gulf of Trieste (Serrazanetti et al. 1994b). These high oleic acid proportions also indicate satisfactory food availability at Stn SJ107 area during those periods. Proportions as high as those at this station were measured in Pseudocalanus elongatus from the North Sea (11 to 16\%), irrespective of seasonal conditions (Kattner \& Krause $1989)$, as well as in winter copepods (16\%) from the Gulf of Trieste (Serrazanetti et al. 1994b). The copepods Acartia clausi, Temora longicornis and Paracalanus parvus, which prevailed in most of the Stn SJ107 samples, generally can combine phytoplankton, organic detritus and younger stages of copepods in their diets (Kattner et al. 1981). Nanoplankton (dominated by flagellates) accounted for the largest part of the phytoplankton chlorophyll a concentrations and abundances at Stn SJ107 (Degobbis et al. 1995). Flagellates are characterized by higher C18:R and C22:6n3 PUFA contents than other phytoplankton species (Mayzaud et al. 1989). Smaller particles (including nanophytoplankton) probably were the most important constituent of zooplankton food at Stn SJ107, resulting in relatively elevated proportions of oleic acid.

In conclusion, large variations in fatty acid composition of the mesozooplankton can occur in the northeastern Adriatic. These variations can in part be explainec by compositional changes in available food. However, great reduction of polyunsaturated fatty acids and $\mathrm{Pr} / \mathrm{C}_{17}$ ratio occurred during the 1991 mucilage event as a result of feeding inhibition and severe food shortage in the water column. These data give insight into the consequences of mucilage events on ecosystem equilibrium and flux of organic matter through the food chain. The impact of the event was particularly serious for the micro-and mesozooplankton communities, which had abundances and diversities significantly below the average levels, because their metabolic needs were not met.
Acknowledgements. The author is grateful to Dr Danilo Degobbis for discussions and critical reading of the manuscript, and to Dr William R. DeNott for useful suggestions The help of CMR divers and the crew of RV 'Vila Velebita' is greatly appreciated. Comments by anonymous reviewers substantially improved the final manuscript. The work is supported by the Ministry of Science and Technology (Project Nos. 1-08-229, 00981303, 00981304) and the State Directorate for the Environment of the Republic of Croatia (Alpe-Adria Project, Observatory for the Northern Adriatıc).

\section{LITERATURE CITED}

Blumer M, Mullin MM, Thomas DW (1964) Pristane in the marine environment. Helgol Wiss Meeresunters 10: $187-201$

Bochdansky AB, Herndl GJ (1992) Ecology of amorphous aggregations (marine snow) in the northern Adriatic Sea. III. Zooplankton interactions with marine snow. Mar Ecol Prog Ser 87:135-146

Crisciani F, Ferraro $S$, Raicich F (1991) Climatological remarks on the algal bloom episodes of 1729 and 1991 in the northern Adriatic Sea. Boll Oceanol Teor Appl 9 : $367-370$

Degobbis D, Fonda-Umani S, Franco P, Malej A, Precali R, Smodlaka $N$ (1995) Changes in the northern Adriatic ecosystem and the hypertrophic appearance of gelatinous aggregates. Sci Total Environ 165:43-58

Donaghay PL, Small LF (1979) Food selection capabilities of the estuarine copepod Acartia clausi. Mar Biol 52:137-146

Ederington MC, McManus GB, Harvey HR (1995) Trophic transfer of fatty acids, sterols, and a triterpenoid alcohol between bacteria, a ciliate, and the copepod Acartia tonsa. Limnol Oceanogr 40:860-867

Hargrave BT, von Bodungen B, Conover RJ, Fraser AJ, Phillips G, Vass WP (1989) Seasonal changes in sedimentation of particulate matter and lipid content of zooplankton collected by sediment trap in the Arctic ocean off Axel Heiberg Island. Polar Biol 9:467-475

Herndl GJ (1992) Marine snow in the Northern Adriatic Sea: possible causes and consequences for a shallow ecosystem. Mar Microb Food Webs 6:149-172

Kaitaranta JK, Linko RR, Vuorela R (1986) Lipids and fatty acids in plankton from the Finnish coastal waters of the Baltic sea. Comp Biochem Physiol 85:427-433

Kattner G (1989) Lipid composition of Calanus finmarchicus from the North Sea and the Arctic. A comparative study. Comp Biochem Physiol 94:185-188

Kattner G. Krause M (1989) Seasonal variation of lipids (wax esters, fatty acids and alcohols) in calanoid copepods from the North Sea. Mar Chem 26:261-275

Kattner G, Krause M, Trahms J (1981) Lipid composition of some typical North sea copepods. Mar Ecol Prog Ser 4: $69-74$

Kleppel GS, Frazel D, Pieper RE, Holliday DV (1988) Natural diets of zooplankton off southern California. Mar Ecol Prog Ser 49:231-241

Knauer GA, Karl DM, Martin JH, Hunter CN (1984) In situ effects of selected preservatives on total carbon, nitrogen and metals collected in sediment traps. J Mar Res 42 : 445-462

Körtzinger A, Schultz-Bull DE, Petrick G, Duinker JC (1994) Evidence for dissolution of fatty acids in sediment traps: impact on flux estimates. J Geophys Res 99:3407-3415

Kršinić F (1995) Microzooplankton assemblages in the northern Adriatic. J Plankton Res 17:935-953 
Lee C, Hedges JI, Wakeham SG, Zhu N (1992) Effectiveness of various treatments in retarding microbial activity in sediment trap material and their effects on the collection of swimmers. Limnol Oceanogr 37:117-130

Lee RF (1974) Lipid composition of the copepod Calanus hyperboreas from the Arctic Ocean: changes with depth and season. Mar Biol 26:313-318

Lee RF, Hirota J, Barnett AM (1971) Distribution and importance of wax esters in marine copepods and other zooplankton. Deep Sea Res 18:1147-1165

Malej A (1995) Gelatinous aggregates in the northern Adriatic Sea. Bull Inst Oceanogr Monaco 15:149-157

Malej A, Harris RP (1993) Inhibition of copepod grazing by diatom exudates: a factor in the development of the mucus aggregates? Mar Ecol Prog Ser 96:33-42

Mayzaud P, Chanut JP, Ackman RG (1989) Seasonal changes of the biochemical composition of marine particulate matter with special reference to fatty acids and sterols. Mar Ecol Prog Ser 56:189-204

Morris RJ (1971) Variations in the fatty acids composition of oceanic euphasiids. Deep Sea Res 18:525-529

Najdek M. (1996) Fatty acid composition in amorphous aggre-

Editorial responsibility: Otto Kinne (Editor),

Oldendorf/Luhe, Germany gates in the northern Adriatic Sea. Mar Ecol Prog Ser 139 219-22

Najdek M, Puškarić S, Bochdansky AB (1994) Contribution of zooplankton lipids to the flux of organic matter in the northern Adriatic Sea. Mar Ecol Prog Ser 111:241-249

Puškarić S, Fowler SW, Miquel JC (1992) Temporal changes in particulate flux in the northern Adratic Sea. Estuar Coast Shelf Sci 35:267-287

Saliot A (1981) Natural hydrocarbons in seawater. In: Duursma EK, Dawson R (eds) Marine organic chemistry. Elsevier, Amsterdam, p 327-374

Serrazanetti GP, Pagnucco C, Conte LS, Artusi R (1994a) Aliphatic hydrocarbons and linear alkylbenzenes in zooplankton from the Gulf of Trieste. Chemosphere 28: $1119-1126$

Serrazanetti GP, Pagnucco C, Conte LS, Artusi R, Fonda-Umani S, Bergami C (1994b) Sterols and fatty acids in zooplankton of the Gulf of Trieste. Comp Biochem Physiol 107:443-446

Volkman JK, Jeffrey SW, Nichols PD, Rogers GI, Garland CD (1989) Fatty acid and lipid composition of 10 species of microalgae used in mariculture. J Exp Mar Biol Ecol 128 $219-240$

Submitted: June 11, 1996; Accepted: July 22, 1997 Proofs received from author(s): November 6, 1997 